\title{
TINJAUAN YURIDIS KASUS KONTAMINASI SUSU FORMULA DALAM PERSPEKTIF PEMBINAAN DAN PENDIDIKAN KONSUMEN
}

\author{
Oleh : Theresia L. Pesulima
}

\begin{abstract}
This study aims to determine the consumer protection system containing legal certainty and transparency of information and access to information.

This study is normative, a study that examines the legal provisions of positive law and legal principles. The data used are secondary data, data obtained through library research and research tools for obtaining secondary data obtained through the study of documents.

The results show that the picture is not clear that information obtained by the public in the case of infant formula reflects that the system of consumer protection provisions contained in the Consumer Protection Act can't be realized the government and the level of knowledgeleducation is uneven between urban communities and suburban/rural. As such, it needs continuous efforts in fostering a critical attitude to the public on the quality of food products so as to encourage the creation of an attitude of prudence consuming public in terms of food products, and the Government should have good communication skills with the public as consumers.
\end{abstract}

Keywords: Contamination of Infant Formula, Development and Consumer Education

\section{A. LATAR BELAKANG.}

Pesatnya pertumbuhan dalam bidang perekonomian terutama dalam bidang perindustrian dan perdagangan nasional telah banyak menghasilkan berbagai variasi barang dan jasa termasuk berbagai jenis produk pangan yang beredar di tengah masyarakat perkotaan maupun pedesaan. Hal ini menimbulkan kebebasan dalam hal memilih aneka jenis produk pangan dan kualitasnya sesuai dengan kemampuan serta keinginan konsumen.

Dalam banyak kasus, posisi seorang konsumen tersebut selalu lebih lemah dibandingkan posisi seorang produsen, sehingga konsumen hanya menjadi obyek bisnis dalam rangka meraih keuntungan sebesar-besarnya melalui propaganda iklan/kiat-kiat promosi, sistem pemasaran, dan pemberlakuan perjanjian standar yang merugikan. Faktor utama lemahnya kedudukan seorang konsumen adalah masih rendahnya tingkat pendidikan atau pengetahuan masyarakat dalam bidang perlindungan konsumen.

Selama ini, banyak kasus di lapangan memperlihatkan bahwa tingkat pengetahuan yang minim membuat seorang konsumen kurang mencermati produk pangan yang dikonsumsinya, misalnya kasus keracunan makanan yang ternyata disebabkan oleh produk pangan yang sudah kadaluwarsa, atau disebabkan oleh kemasan yang rusak karena kontaminasi, dan lain sebagainya. Sedangkan kasus yang cukup fenomenal akhir-akhir ini adalah hasil penelitian tim peneliti Institut Pertanian Bogor yang menemukan fakta bahwa produk susu formula bayi dan makanan bayi yang dipasarkan antara bulan April-Juni 2006 tercemar oleh mikroba yang bernama entrobacter sakazakii (ES). Dari 22 sampel susu formula yang telah diteliti terdapat $22,73 \%$ yang terkontaminasi entrobacter sakazakii (ES) dan 15 sampel makanan bayi 
yang diteliti terdapat $40 \%$ telah terkontaminasi entrobacter sakazakii (ES). Yang menarik dari kasus ini adalah polemik antara lembaga penelitian IPB dan pemerintah (Menkes RI) berkembang sedemikian rupa sehingga menjadi polemik yang bernuansa politis, dimana masingmasing pihak melakukan manuver saling menjatuhkan, sehingga masyarakat semakin resah dan kedudukannya selaku pihak konsumen sangat dirugikan.

Kasus yang mencuat sekitar bulan Februari 2008 baru mendapat kejelasan pada tanggal 3 April 2008 dengan adanya pengumuman resmi dari Kepala Badan Pengawas Obat dan Makanan (BPOM) selaku instansi pemerintah yang mempunyai wewenang tertinggi di bidang peredaran obat dan makanan di Indonesia. Namun, pengumuman dari pemerintah yang sekian lama ditunggu-tunggu oleh masyarakat ini ternyata tidak cukup memuaskan. Harapan masyarakat bahwa nama-nama (merek) produk susu formula dan makanan bayi yang tercemar tersebut akan diumumkan ternyata tidak dilakukan oleh BPOM. Pemerintah hanya menyatakan bahwa telah dilakukan penelitian yang sama terhadap produkproduk yang semula telah dinyatakan tercemar oleh tim peneliti IPB, dan hasil pengujian ulang oleh pemerintah tersebut menunjukan bahwa produk-produk susu formula dan makanan bayi yang beredar di pasaran telah dinyatakan aman. Banyak kalangan menilai, bahwa upaya penyimpulan 96 sampel susu formula bebas bakteri Entrobacter sakazakii oleh BPOM itu mengindikasikan bahwa pemerintah masih menjadi corong pengusaha. Pernyataan ini dilontarkan oleh Arist Merdeka Sirait selaku Sekretaris Jenderal Komisi Nasional Perlindungan Anak. Ia berpendapat bahwa seharusnya pemerintah melakukan langkah untuk mengumumkan nama-nama (merek) produk susu formula yang tercemar terlebih dahulu, baru melakukan penelitian ulang terhadap produk-produk tersebut.
Dalam ketentuan UU No. 7 Tahun 1996 tentang Pangan disebutkan bahwa seorang produsen pangan wajib memenuhi persyaratan keamanan, mutu, dan gizi pangan. Sehingga kegiatan atau proses produksi pangan untuk diedarkan atau diperdagangkan harus memenuhi ketentuan sanitasi pangan, bahan tambahan makanan pangan, residu cemaran, dan kemasan pangan. Demikian pula ketentuan dalam UU No. 8 tahun 1999 tentang Perlindungan Konsumen yang melarang pelaku usaha memperdagangkan barang yang rusak, cacat atau bekas, dan tercemar tanpa memberikan informasi secara lengkap dan benar atas barang dimaksud. Kedua ketentuan tersebut mengatur kewajiban para pelaku usaha atau produsen dengan maksud melindungi kepentingan para konsumen atau pengguna barang dan/atau jasa tersebut.

Namun demikian, pasal 5 UU Perlindungan Konsumen menyebutkan bahwa kewajiban seorang konsumen adalah melakukan upaya hati-hati dan menggunakan ketelitiannya sewaktu membeli suatu produk barang dan/atau jasa, termasuk produk pangan. Jadi, jika ditinjau dari sisi kedudukan seorang konsumen, iapun mempunyai kewajiban yang harus dilakukan terlebih dahulu sebelum memutuskan untuk membeli dan mengkonsumsi produk pangan tersebut.

Produsen atau pelaku usaha mempunyai tanggung jawab terhadap kualitas produk pangan yang dihasilkannya sedangkan pada sisi lain, seorang konsumen wajib dan perlu melakukan kehati-hatian dalam mengkonsumsi produk pangan tersebut. Hal ini sesuai dengan doktrin atau teori hukum perlindungan konsumen "Let The Buyer Beware"yang mempunyai asumsi bahwa pelaku usaha dan konsumen merupakan dua pihak yang sangat seimbang sehingga tidak diperlukan proteksi apapun bagi si konsumen. Jadi dapat disimpulkan, bahwa seorang konsumen tersebut mempunyai kewajiban berusaha melindungi dirinya sendiri. 
Mengingat sebuah produk pangan yang telah memenuhi standar kesehatan, dalam perjalanan waktu bisa menjadi produk pangan yang tidak layak konsumsi karena kemasan rusak akibat pengangkutan, kadaluwarsa, dan lain-lain, maka upaya paling penting adalah memberikan pengetahuan yang cukup kepada masyarakat sebagai pengguna produk pangan untuk memahami kewajibannya sebagai konsumen agar bersikap kritis dan berhati-hati dalam menggunakan produk pangan sehingga bisa mengeliminir kerugian. Belajar dari kasus susu formula yang terkontaminasi, dimana pemerintah tidak dapat segera mengambil sikap yang mencerminkan jaminan kepastian hukum, sehingga memberikan jaminan kenyamanan bagi konsumen dalam mengkonsumsi produk, maka yang paling urgen dilakukan adalah upaya untuk mendidik masyarakat agar menjadi konsumen yang cerdas (cerdas akan hak dan kewajibannya).

Masyarakat pedesaan yang pada umumnya merupakan kelompok masyarakat yang lebih jauh akses informasinya dibandingkan dengan kelompok masyarakat perkotaan, menjadikannya lebih rentan terhadap potensi kerugian akibat minimnya pengetahuan untuk bersikap hati-hati dalam menggunakan dan mengkonsumsi produkproduk pangan tersebut. Oleh karena itu diperlukan sebuah upaya preventif untuk mengatasinya, dimana salah satunya melalui program pendidikan kepada masyarakat tersebut, yaitu dengan memberikan pegetahuan dalam bidang perlindungan konsumen dalam rangka mengupayakan kesadaran untuk bersikap kritis dan selanjutnya berhati-hati dalam mengkonsumsi produk pangan.

Berdasarkan uraian analisis situasi yang telah dipaparkan di atas, maka dapat dikemukakan permasalahan sebagai berikut :

"Bagaimana menciptakan sistem perlindungan konsumen yang mengandung kepastian hukum \& keterbukaan informasi serta akses untuk mendapatkan informasi?"

\section{B. PEMBAHASAN}

Istilah "konsumen" secara formal definisinya dapat kita temukan pada Undang-Undang Nomor 8 Tahun 1999 tentang Perlindungan Konsumen (selanjutnya disingkat UUPK). Dalam ketentuan UUPK yang dinamakan konsumen adalah setiap orang pemakai barang dan/atau jasa yang tersedia dalam masyarakat, baik bagi kepentingan diri sendiri, keluarga, orang lain, maupun mahkluk hidup lain dan tidak untuk diperdagangkan. Sedangkan pegertian dari pelaku usaha dapat kita temukan pada ketentuan pasal 1 butir 3 yang intinya adalah mereka (baik perorangan maupun badan usaha) yang menyelenggarakan kegiatan dalam bidang ekonomi. Secara umum lahirnya peraturan dalam bidang perlindungan konsumen ini merupakan suatu bentuk upaya pemerintah untuk menjaga iklim usaha yang sehat dan upaya terciptanya keseimbangan kedudukan antara pelaku usaha dan para konsumen. Sebab seperti telah lama diketahui, bahwa pesatnya perkembangan dalam bidang perindustrian dan perdagangan mengakibatkan kedudukan yang tidak seimbang antara pelaku usaha dengan konsumen, dimana konsumen cenderung hanya menjadi obyek bisnis untuk meraih keuntungan. Oleh karena itu, dalam UU ini dimuat ketentuan mengenai hak dan kewajiban, baik bagi para pelaku usaha maupun bagi para konsumen.

Hak dan kewajiban pelaku usaha diatur dalam ketentuan pasal 6 dan 7 UUPK, dimana kewajibannya adalah beretikad baik dalam menjalankan kegiatan usahanya tersebut, antara lain dengan memberikan informasi yang benar, jelas, jujur mengenai kondisi dan jaminan barang dan/atau jasa serta memberikan penjelasan mengenai penggunaan, perbaikan dan pemeliharaannya. Selanjutnya, menjaga mutu barang dan/atau jasa yang diproduksi dan /atau diperdagangkan berdasarkan ketentuan standar mutu barang dan/atau jasa yang berlaku. Selain itu, pelaku usaha juga 
berkewajiban untuk memberikan kompensasi apabila terjadi kerugian akibat penggunaan, pemakaian dan/atau penggunaan barang dan/atau jasa yang diperdagangkan itu. Sedangkan hak-haknya selaku pelaku usaha adalah menerima pembayaran yang sesuai dengan kesepakatan dan kondisi/nilai barang dan/atau jasa tersebut. Selain itu, ia berhak mendapat perlindungan hukum dari pihak konsumen yang memiliki itikad tidak baik, berhak melakukan pembelaan diri sepatutnya, serta berhak untuk direhabilitasi nama baiknya yang sudah terlanjur tercemar apabila telah terbukti bahwa kerugian konsumen tersebut bukan diakibatkan oleh produk barang dan/atau jasa yang diproduksinya.

Industri pangan yang menghasilkan produk-produk pangan mempunyai tanggung jawab untuk menjamin keamanan pangan yang diproduksinya. Ketentuan ini telah diatur dalam Undang-Undang No. 7 tahun 1996 tentang Pangan, pasal 41 s/d 44 dan hal ini sejalan dengan ketentuan pasal 7 UUPK, yang menetapkan kewajiban para pelaku usaha untuk menjamin mutu barang dan atau jasa yang diproduksi dan atau diperdagangkan berdasarkan ketentuan standar mutu barang dan atau jasa yang berlaku. Sehingga tanggung jawab industri pangan merupakan aspek penting dalam mewujudkan perlindungan terhadap hak-hak konsumen sebagai pemakai produk-produk pangan sebagaimana tersebut dalam ketentuan pasal 4 UUPK.

Sementara di lain pihak, ketentuan mengenai kewajiban konsumen diatur juga yaitu dalam pasal 5 UUPK, antara lain :

1. Membaca atau mengikuti petunjuk informasi dan prosedur pemakaian atau pemanfaatan barang dan/atau jasa, demi keamanan dan keselamatan.

2. Beritikad baik dalam melakukan transaksi pembelian barang dan/atau jasa.

3. Membayar sesuai dengan nilai tukar yang disepakati.
4. Mengikuti upaya penyelesaian hukum sengketa perlindungan konsumen secara patut.

Jika kita mencermati ketentuan dari pasal 5 tersebut, maka jelas bahwa tanggung jawab dalam hal keselamatan produk tidak hanya dibebankan sepenuhnya pada pihak pelaku usaha atau produsen. Pihak konsumen sebagai pengguna produk juga mempunyai kewajiban untuk mengupayakan keselamatan dirinya dalam mengkonsumsi produk-produk yang dihasilkan oleh produsen, yaitu dengan melakukan upaya kehati-hatian sebelum membelinya.

Mengingat selama ini upaya penyadaran dalam hal perlindungan konsumen lebih menitikberatkan pada sisi pelaku usaha, maka timbul sebuah asumsi dalam masyarakat bahwa peraturan mengenai perlindungan konsumen dibuat untuk membebani para pengusaha dengan sebuah tanggung jawab berat dalam menjaga keselamatan dan kenyamanan bagi para pengguna produk (sesuai ketentuan pasal 4 UUPK), dan fakta di lapangan masih sedikit upaya sosialisasi mengenai aspek kewajiban masyarakat luas selaku konsumen sebagai bagian dari hak masyarakat untuk mendapatkan pembinaan dan pendidikan di bidang konsumen. Padahal, seperti kita ketahui sistem perlindungan konsumen yang diatur dalam ketentuan UUPK berupaya menciptakan sebuah kerangka hukum yang dapat menumbuhkan iklim usaha dan hubungan yang sehat antara pelaku usaha dan konsumen.

Dari kasus susu formula dan makanan bayi yang tercemar entrobacter sakazakii, kita dapat menganalisa bahwa pemerintah sendiri belum sepenuhnya memberikan hak-hak masyarakat selaku konsumen sebagaimana termaktub dalam tujuan perlindungan konsumen pasal 3 UUPK, terutama pasal 3 huruf $\mathrm{c}$ yang membebankan kewajiban pemerintah dalam menciptakan suatu sistem perlindungan konsumen yang mengandung unsur kepastian hukum dan keterbukaan informasi serta akses untuk mendapatkan informasi. 
Dan pengaturan ini juga tercermin dalam ketentuan yang mengatur hak dan kewajiban masyarakat selaku konsumen, yaitu dalam pasal 4 huruf $\mathrm{C}$ (tentang kejelasan informasi produk) dan $F$ (hak untuk dibina melalui program pendidikan konsumen agar menjadi konsumen yang cerdas). Kesimpang-siuran informasi yang didapat oleh masyarakat dalam kasus susu formula tersebut mencerminkan bahwa sistem perlindungan konsumen yang termaktub dalam ketentuan pasal 3 UUPK belum dapat diwujudkan pemerintah. Menurut penulis, sistem tersebut dapat terwujud jika pemerintah memilliki kemampuan good communicater dengan masyarakatnya, dan pejabat publiknya lebih bisa menata diri ketika akan mengeluarkan pernyataan di depan publik. Sehingga, unsur kepastian hukum tersebut berdampak pada kenyamanan masyarakat selaku konsumen pengguna produk. Begitu juga dengan kewajiban yang dibebankan kepada masyarakat selaku konsumen untuk bersikap hati-hati (Pasal 5 UUPK), tidak akan terwujud jika masyarakat sendiri tidak diberikan bekal pengetahuan untuk menjadi konsumen yang cerdas. Terlebih dengan tingkat pengetahuan/pendidikan yang tidak merata antara kelompok masyarakat perkotaan dan pinggiran/pedesaan, maka upaya sosialisasi mengenai aspek kewajiban konsumen ini perlu diintensifkan serta diprioritaskan pada kelompok masyarakat pedesaan yang secara geografis maupun sosial jauh dari akses informasi yang dibutuhkannya.

\section{P E N U T UP}

\section{Kesimpulan}

Dari uraian pembahasan di atas, maka dapat diambil suatu kesimpulan bahwa menciptakan sistem perlindungan konsumen yang mengandung kepastian hukum \& keterbukaan informasi serta akses untuk mendapatkan informasi antara lain dengan langkah-langkah:
1. Pemerintah harus memiliki kemampuan berkomunikasi yang baik dengan masyarakat selaku konsumen.

2. Melakukan upaya yang berkesinambungan dalam menumbuhkan sikap kritis pada masyarakat terhadap kualitas produk pangan sehingga mendorong terciptanya sikap kehati-hatian masyarakat dalam hal mengkonsumsi produk pangan dan hal tersebut hanya dapat dicapai dengan memberikan hak konsumen yaitu haknya untuk mendapatkan pembinaan dan pendidikan di bidang konsumen.

\section{Saran}

Adapun saran-saran yang dapat diberikan antara lain sebagai berikut:

1. Secara umum lahirnya peraturan dalam bidang perlindungan konsumen ini merupakan suatu bentuk upaya pemerintah untuk menjaga iklim usaha yang sehat dan upaya terciptanya keseimbangan kedudukan antara pelaku usaha dan para konsumen, sehingga pemerintah diharapkan tidak hanya mementingkan kepentingan pihak pengusaha saja.

2. Program pendidikan di bidang konsumen dapat dilakukan (direaliasikan) dengan bekerjasama dengan institusi perguruan tinggi dan LSM.

3. Sebaiknya dialokasikan dana untuk menangani penelitian-penelitian di bidang konsumen untuk mengetahui perkembangan permasalahan perlindungan konsumen, sehingga dapat dirumuskan berbagai alternatif pemecahan masalah tersebut. 


\section{DAFTAR PUSTAKA}

Miru Ahmad dan Sutarman Yodo, 2004, Hukum Perlindungan

Konsumen, PT. Raja

Grafindo Persada, Bandung.

Rajaguguk Erman,dkk, 2000, Hukum Perlindungan Konsumen, Mandar Maju, Bandung.

Sudaryatmo, 1999, Hukum Dan Advokasi Konsumen, PT. Citra Aditya, Bandung.

Undang-Undang Nomor 8 Tahun 1999, Tentang Perlindungan

Konsumen.

Undang-Undang Nomor 7 Tahun 1996, Tentang Pangan.

Koran Tempo, edisi Jumat 4 April 2008. 